\title{
PERAN KEPALA SEKOLAH DASAR DALAM MEMPERSIAPKAN SUMBER DAYA PENDIDIK MENGHADAPI IMPLEMENTASI KURIKULUM 2013
}

\author{
Badarudin Badarudin \\ Universitas Muhammadiyah Purwokerto, Purwokerto, Indonesia \\ Email: badar_ump@yahoo.co.id
}

\begin{abstract}
School principals as leaders in primary schools can be a good manager of school progress in the future as well designer. The principal's role is very important, because in the hands of the principal policies will progress the school is located. Factors supporting the achievement of a program created by the principal, the teacher's role as an educator as a resource executing the implementation of curriculum 2013, would require the improvement and enhancement of professionalism. Principal's role in preparing resource educator (teacher) facing the implementation of the curriculum in 2013 as a planner and developer in providing a school policy is to increase learning in terms of services, the concept of a credible form of learning that applies the concept of thematic scientific approach, foster harmonious school climate and culture character that can be run in a conducive learning, academic educators increase the professionalism through education and training, and instilling cohesion and cooperation among stakeholders in building and developing a school program.
\end{abstract}

Keywords: Principle, Educator, Curriculum

Kepala sekolah sebagai pimpinan di SD harus dapat menjadi manejer yang baik sekaligus perancang kemajuan sekolah kedepannya. Peran kepala sekolah sangat penting, karena di tangan kepala sekolah kebijakan-kebijakan akan kemajuan sekolah berada. Faktor pendukung tercapainya program yang dibuat oleh kepala sekolah, peran guru sebagai sumber daya pendidik sebagai pelaksana implementasi kurikulum 2013, tentunya memerlukan perbaikan dan peningkatan secara profesionalitas. Peran kepala sekolah dalam mempersiapkan sumber daya pendidik (guru) menghadapi implementasi kurikulum 2013 yaitu sebagai perencana dan pengembang dalam memberikan sebuah kebijakan sekolah yaitu dengan peningkatan dari segi pelayanan pembelajaran, konsep kegaitan pembelajaran yang menerapkan konsep pendekatan tematik scientific, menumbuhkan iklim budaya sekolah yang harmonis dan berkarakter sehingga pembelajaran dapat berjalan secara kondusif, peningkatan profesionalitas akademik pendidiknya melalui jalur pendidikan dan pelatihan, dan menanamkan kebersamaan serta kerja sama antar stakeholder dalam membangun dan mengembangkan program sekolah.

Kata Kunci : Kepala Sekolah, Pendidik, Kurikulum 2013

\section{PENDAHULUAN}

Kemajuan Ilmu Pengetahuan dan Teknologi (IPTEK) yang semakin pesat, menuntut kita untuk senantiasa meningkatkan segala kemampuan yang kita miliki agar mampu mengimbangi segala kemajuan tersebut. Salah satu upaya yang dapat dilakukan dalam mempersiapkan diri terhadap kemajuan IPTEK adalah melalui pendidikan. Dalam Undang-undang Nomor 20 Tahun 2003 tentang Sistem Pendidikan Nasional 74
Pasal 1 ayat 1 , dinyatakan pendidikan adalah usaha sadar dan terencana untuk mewujudkan suasana belajar dan proses pembelajaran agar peserta didik secara aktif mengembangkan potensi dirinya untuk memiliki kekuatan spiritual keagamaan, pengendalian diri, kepribadian, kecerdasan, ahlak mulia, serta keterampilan yang diperlukan bangsa dan negara. Mengingat pentingnya pendidikan dalam kehidupan manusia, maka pendidikan harus dapat membawa dan mengarahkan 
peserta didik untuk mengembangkan segala potensi yang dimilikinya yang dapat diaplikasikannya pada kehidupannya, baik di lingkungan keluarga maupun masyarakat.

Sekolah dasar (SD) sebagai wahana tempat mendidik pada jenjang dasar merupakan lembaga yang sangat berperan penting dalam mencipkan sumber daya manusia yang berkualitas, pada jenjang ini anak mulai mengenal pendidikan formal sebagai dasar fundamental pembentukan karakteristik dan pondasi pengetahuan awal. Kepala sekolah sebagai pimpinan di SD harus dapat menjadi manejer yang baik sekaligus perancang kemajuan sekolah kedepannya. Peran kepala sekolah sangat penting, karena di tangan kepala sekolahlah kebijakankebijakan akan kemajuan sekolah berada.

Guru sebagai salah satu stakeholder merupakan faktor pendukung tercapainya program yang dibuat oleh kepala sekolah, peran guru sebagai tenaga pengajar tentunya memerlukan perbaikan peningkatan profesionalitas sehingga materi yang nanti akan diberikan kepada peserta didik dapat menjawab tujuan dari kurikulum 2013, yaitu mempersiapkan manusia Indonesia agar memiliki kemampuan hidup sebagai pribadi dan warga negara yang beriman, produktif, kreatif, inovatif, dan afektif serta mampu berkontribusi pada kehidupan bermasyarakat, berbangsa, bernegara, dan peradaban dunia. (Salinan Lampiran Permendikbud No. 67 Tahun 2013: 4).

Tujuan tersebut dapat dicapai apabila sumber daya pengajar dikelola dan ditingkatkan kapasitas serta kapabilitas dalam hal pelayanan, perilaku, pengajaran, penataan ruang belajar, manajemen sekolah, dan peningkatan profesionalitas melalui studi pendidikan ke jenjang yang lebih tinggi. Berdasarkan uraian tersebut, artikel ini akan membahas peran kepala sekolah dalam mempersiapkan sumber daya pendidik menghadapi implementasi kurikulum 2013.

\section{PEMBAHASAN}

\section{Peran Kepala Sekolah}

Urgensi dan peranan kepala sekolah didasarkan pada pemahaman bahwa keberhasilan sekolah merupakan keberhasilan kepala sekolah. Oleh karena itu, kepala sekolah perlu memiliki kompetensi yang disyaratkan agar dapat merealisasikan visi dan misi yang diemban sekolahnya. Dalam kerangka ini direkomendasikan mereaktualisasi fungsi dan peranan kepala sekolah dalam wujud good school governance. Untuk mewujudkan visi dan misi pendidikan di tingkat satuan pendidikan perlu ditunjang oleh kemampuan kepala sekolah yang handal dalam menjalankan fungsi dan peranannya. Meskipun pengangkatan kepala sekolah dilakukan secara terencana dan sistematis, bahkan diangkat dari guru yang sudah berpengalaman atau mungkin sudah lama menjabat sebagai wakil kepala sekolah, namun tidak otomatis membuat kepala sekolah profesional dalam melakukan tugasnya. Pada beberapa kasus ditunjukkan adanya kepala sekolah yang terpaku dengan urusan administratif yang sebenarnya bisa dilimpahkan kepada Tenaga Administrasi Sekolah (TAS).

Sejumlah pakar sepakat bahwa kepala sekolah harus mampu melaksanakan pekerjaannya sebagai edukator, manajer, administrator dan supervisor, yang disingkat EMAS. Dalam perkembangan selanjutnya, sesuai dengan kebutuhan masyarakat dan perkembangan zaman, kepala sekolah juga harus mampu berperan sebagai leader, inovator dan motivator di sekolahnya, dengan demikian, dalam paradigma baru manajemen pendidikan, kepala sekolah minimal harus mampu berfungsi sebagai edukator, manajer, administrator, supervisor, leader, 
inovator dan motivator, disingkat EMASLIM.

Perspektif ke depan mengisyaratkan bahwa kepala sekolah juga harus mampu berperan sebagai figur dan mediator bagi perkembangan masyarakat dan lingkungan. Jika mengacu pada Peraturan Menteri Pendidikan Nasional Republik Indonesia Nomor 13 Tahun 2007 tentang Standar Kepala Sekolah/Madrasah, maka kepala sekolah juga harus berjiwa wirausaha. Dengan demikian, pekerjaan kepala sekolah semakin hari semakin meningkat dan akan selalu meningkat sesuai dengan perkembangan pendidikan yang diharapkan, dalam hal ini pekerjaan kepala sekolah tidak hanya dalam kerangka EMASLIM, tetapi akan berkembang menjadi EMASLIM-F karena kepala sekolah juga sebagai pejabat formal. Semua itu harus dipahami oleh kepala sekolah dan yang lebih penting adalah bagaimana kepala sekolah mampu mengamalkan dan menjadikan fungsifungsi tersebut dalam bentuk aksi nyata di sekolah. Pelaksanaan tugas dan fungsi kepala sekolah tidak dapat dipisahkan satu sama lain karena saling terkait dan saling mempengaruhi serta menyatu dalam pribadi seorang kepala sekolah profesional. Kepala sekolah yang demikian akan mampu mendorong visi dan misi menjadi aksi dalam paradigma baru manajemen pendidikan.

\section{Peran Sumber Daya Pendidik (Guru)}

Guru menurut Undang-Undang Nomor 14 Tahun 2005 adalah pendidik profesional yang tugas utama mendidik, mengajar, membimbing, mengarahkan, melatih, menilai, dan mengevaluasi peserta didik pada pendidikan anak usia dini jalur pendidikan formal, pendidikan dasar dan pendidikan menengah. Tugas guru sebagai pendidik mempuyai makna ganda, yaitu guru harus dapat membuat peserta didiknya pintar dalam hal pelajaran sekaligus juga membimbing peserta didiknya agar berprilaku baik. Guru pendidik bertugas tidak sebatas sebagai guru di dalam kelas saja, tetapi juga di luar kelas. Dengan demikian, predikat guru pendidik lebih baik dibanding dengan guru pengajar. Memdidik merupakan aktivitas untuk menjadikan peserta didik berprilaku baik. Pendidikan yang diajarkan oleh guru tersebut memberikan dasar dalam hal guru selalu memberikan penguatan dan tidak menyalahkan, melainkan memberikan motivasi belajar agar peserta didik tidak patah semangat.

Guru juga mempunyai tugas untuk membesarkan sekolahnya, misalnya, mengajar dengan sungguh-sungguh sehingga peserta didiknya dapat melanjutkan ke jenjang sekolah yang diidam-idamkan, membimbing peserta didiknya mengikuti berbagai perlombaan sehingga dapat memenangkannya. Hal itu perlu dilakukan agar peserta didik mempunyai kemampuan kognitif, psikomotor, dan afektif secara seimbang.

Menjadi guru menarik merupakan suatu dambaan bagi setiap orang. Guru dikatakan menarik bagi peserta didiknya, orang tua wali murid maupun rekan guru lain jika guru tersebut dapat membangun simpati dengan orang lain. Untuk memperoleh simpati dari orang lain tidak cukup hanya sekedar rajin menebar senyum atau berdandan secara berlebihan. Lebih dari itu, guru harus dapat mencerminkan citra sebagai guru profesional. Ketika guru telah dapat menarik simpati peserta didiknya, maka dapat dipastikan materi pelajaran yang disampaikan juga menarik. Kalau materi pelajaran yang diajarkan oleh gurunya 
sudah menarik bagi peserta didik, maka peluang keberhasilan dalam pembelajaran itu semakin tinggi. Dalam buku yang berjudul "Rahasia Menjadi Guru Hebat, Motovasi Diri Menjadi Guru Luar Biasa karangan Mulyana A.Z.", dikatan bahwa untuk menjadi guru yang hebat perlu mencermati langkah berikut:

a. Mengenali potensi diri

b. Mempuyai mimpi untuk menjadi hebat

c. Membuat perencanaan yang matang

d. Menguasai teori komunikasi dengan matang,

e. Mampu membangun team work yang kuat

f. Mampu membangun networking yang kuat

g. Menguasai metode pembelajaran dengan baik

h. Mampu mengelola pembelajaran dengan baik

i. Mempunyai semagat belajar yang kuat. (Mulyana, 2010:6)

Kepribadian bagi seorang guru mempunyai andil yang cukup besar dalam menentukan identitas menarik atau tindakanya guru di mata orang lain. Karena kepribadian itulah yang membentuk karakter seseorang menjadi pribadi yang baik atau tidak baik. Jika pribadi yang baik telah dimiliki oleh seseorang maka pribadi yang baik tersebut dapat melahirkan karakter yang menarik, berupa prilaku, etika pergaulan, dan jalinan komunikasi. Ketika telah disadari bahwa guru menjadi salah satu profesi, maka tanggung jawab kita menjadi luas dan tidak ringan serta dibutuhkan keikhlasan. Tanggung jawab profesional itu adalah sebagai berikut:

a. Guru seharusnya memberikan yang terbaik bagi peserta didik.

b. Guru seharusnya menyiapkan materi pembelajaran dengan baik, mulai dari RPP, materi yang akan diajarkan, media pembelajaran, dan alat evauasinya.

c. Guru seharusnya selalu mengembangkan kompetensinya melalui seminar, workshop, lokakarya, semiloka, diklat, dan sebagainya.

d. Guru harus mampu membangun jaringan dengan sesama guru, organisasi keguruan, atau dengan perilaku pendidikan yang lainnya.

Tanggung jawab guru yang lain adalah

a. Guru bertanggung jawab sebagai pendidik

b. Guru bertanggung jawab terhadap profesinya

c. Guru bertanggung jawab sebagai pengajar

d. Guru bertanggung jawab sebagai bpendamping dan pembimbing peserta didik

e. Guru sebagai pengembang kurikulum mulai dari silabus, RPP, dan rekayasa yang lainnya, dan

f. Guru bertanggung jawab terhadap pengelolaan kelas dan menangani administrasinya.

(Mulyana, 2010:40)

Etos kerja seseorang sangat berpengaruh kepada produktivitas yang akan dihasilkan. Etos kerja yang jelek mengakibatkan produktivitas yang jelek. Sebaliknya, etos kerja yang baik menghasilkan produktivitas yang baik pula. Sebagai guru, etos kerja itu sangat penting, karena sebesar apapun etos kerjanya sangat menentukan produktivitas yang akan dihasilkannya. Jika etos kerja mereka baik maka dapat dipastikan orang lain akan tertarik. Kinerja guru dikatakan baik jika guru dapat melaksanakan tugasnya dengan baik, mulai menyiapkan perangkat pembelajaran berupa Rencana Pelaksanaan Pembelajaran (RPP), silabus, menyiapkan media pembelajarannya serta menyiapkan berbagai administrasi lainnya. 
Setelah menyiapkan segala keperluan pembelajaran, guru tersebut juga harus mengajar di depan kelas dengan baik. Dengan demikian, target kurikulum dan target penguasaan materi oleh peserta didik dapat tercapai. Jika proses pembelajaran telah dilaksanakan dengan baik maka guru juga harus mampu membuat evaluasi bagi peserta didiknya. Jika tugas-tugas tersebut dapat dilakukan dengan baik maka akan mengundang simpati dan ketertarikan orang lain.

\section{Implementasi Kurikulum 2013}

Undang-Undang Nomor 20 Tahun 2003 tentang Sistem Pendidikan Nasional menyebutkan bahwa kurikulum adalah seperangkat rencana dan pengaturan mengenai tujuan, isi, dan bahan pelajaran serta cara yang digunakan sebagai pedoman penyelenggaraan kegiatan pembelajaran untuk mencapai tujuan pendidikan tertentu. Berdasarkan pengertian tersebut, ada dua dimensi kurikulum, yang pertama adalah rencana dan pengaturan mengenai tujuan, isi, dan bahan pelajaran, sedangkan yang kedua adalah cara yang digunakan untuk kegiatan pembelajaran.

Kurikulum 2013 bertujuan untuk mempersiapkan manusia Indonesia agar memiliki kemampuan hidup sebagai pribadi dan warga negara yang beriman, produktif, kreatif, inovatif, dan afektif serta mampu berkontribusi pada kehidupan bermasyarakat, berbangsa, bernegara, dan peradaban dunia. Kurikulum 2013 dikembangkan dengan penyempurnaan pola pikir sebagai berikut:

a. Pola pembelajaran yang berpusat pada guru menjadi pembelajaran berpusat pada peserta didik. Peserta didik harus memiliki pilihan-pilihan terhadap materi yang dipelajari untuk memiliki kompetensi yang sama;

b. Pola pembelajaran satu arah (interaksi guru-peserta didik) menjadi pembelajaran interaktif (interaktif guru-peserta didikmasyarakat-lingkungan alam, sumber/ media lainnya);

c. Pola pembelajaran terisolasi menjadi pembelajaran secara jejaring (peserta didik dapat menimba ilmu dari siapa saja dan dari mana saja yang dapat dihubungi serta diperoleh melalui internet);

d. Pola pembelajaran pasif menjadi pembelajaran aktif-mencari (pembelajaran peserta didik aktif mencari semakin diperkuat dengan model pembelajaran pendekatan sains);

e. Pola belajar sendiri menjadi belajar kelompok (berbasis tim);

f. Pola pembelajaran alat tunggal menjadi pembelajaran berbasis alat multimedia;

g. Pola pembelajaran berbasis massal menjadi kebutuhan pelanggan (users) dengan memperkuat pengembangan potensi khusus yang dimiliki setiap peserta didik;

h. Pola pembelajaran ilmu pengetahuan tunggal

(monodiscipline) menjadipembelajaran ilmu pengetahuan jamak (multidisciplines); dan

i. Pola pembelajaran pasif menjadi pembelajaran kritis.

Pelaksanaan kurikulum selama ini telah menempatkan kurikulum sebagai daftar matapelajaran. Pendekatan Kurikulum 2013 untuk Sekolah Dasar/Madrasah Ibtidaiyah diubah sesuai dengan kurikulum satuan pendidikan. Oleh karena itu dalam Kurikulum 2013 
dilakukan penguatan tata kelola sebagai berikut:

a. Tata kerja guru yang bersifat individual diubah menjadi tata kerja yang bersifat kolaboratif;

b. Penguatan manajeman sekolah melalui penguatan kemampuan manajemen kepala sekolah sebagai pimpinan kependidikan (educational leader); dan

c. Penguatan sarana dan prasarana untuk kepentingan manajemen dan proses pembelajaran.

Kurikulum 2013 dirancang dengan karakteristik sebagai berikut:

a. Mengembangkan keseimbangan antara pengembangan sikap spiritual dan sosial, rasa ingin tahu, kreativitas, kerja sama dengan kemampuan intelektual dan psikomotorik;

b. Sekolah merupakan bagian dari masyarakat yang memberikan pengalaman belajar terencana dimana peserta didik menerapkan apa yang dipelajari di sekolah ke masyarakat dan memanfaatkan masyarakat sebagai sumber belajar;

c. Mengembangkan sikap, pengetahuan, dan keterampilan serta menerapkannya dalam berbagai situasi di sekolah dan masyarakat;

d. Memberi waktu yang cukup leluasa untuk mengembangkan berbagai sikap, pengetahuan, dan keterampilan;

e. Kompetensi dinyatakan dalam bentuk kompetensi inti kelas yang dirinci lebih lanjut dalam kompetensi dasar matapelajaran;

\section{Stategi dalam Mempersiapkan Sumber Daya Pendidik Menghadapi Implementasi Kurikulum 2013}

a. Pelayanan
Pelayanan merupakan aspek yang di dahulukan, pelayanan yang baik terhadap orang tua wali peseta didik, peserta didik atau bahkan warga sekolah merupakan manajemen sekolah dalam mendesain model pelayanan yang lebih komunikatif, karena dalam tata kelola manajemen marketing, pelayanan memegang peranan penting dalam memberikan kepuasan kepada orang lain. Ketika seseorang merasa terpuaskan, maka ia akan dapat melakukan aktivitasnya dengan penuh rasa gembira. Dengan demikian pelayanan model lama harus diubah dengan pelayanan model baru, yang lebih mementingkan pelanggan.

Peran guru harus dapat menjembatani informasi yang ada di sekolah yang berkaitan dengan proses pemelajaran kepada orang tua wali peserta didik, guru juga harus dapat bertindak seperti konselor, yaitu orang yang dapat memberikan bimbingan bukan pada peserta didik saja melainkan bisa menerima masukkan dan memfasilitasi keinginan orang tua demi kemajuan prestasi belajar anaknya di sekolah. Hubungan guru dan orang tua wali murid harus terjalin secara sinergis, karena berawal dari kepercayaan orang tua wali murid pada sekolah, yang merupakan aset sangat berharga bagi sekolah. Sehingga, sekolah dapat berkembang dan dapat menjalankan semua program yang telah direncanakan.

\section{b. Perilaku pelaku pendidikan yang ada di dalamnya}

Sekolah yang di dalamnya terdapat kepala sekolah, guru dan karyawan sebisa mungkin mereka semua juga harus mampu bertindak dan berperan sebagai marketing sekolah. Walaupun dalam jobdis pekerjaannya seorang penjaga sekolah tidak harus memasarkan 
produknya dari calon wali murid yang satu ke calon mali murid yang lainnya, tetapi paling tidak seorang penjaga sekolah juga harus paham tentang kekurangan dan kelebihan dari sekolah tersebut. Sehingga seorang penjaga sekolah akhirnya akan mampu memerankan sebagai marketing yang handal. Sehingga ketika calon wali murid datang ke sekolah dan bertanya tentang sistem pendaftaran murid sampai dengan model pembelajarannya seorang penjaga sekolah harus mampu memberikan penjelasan secara rinci. Keberadaan guru disekolah tidak sekedar menjalankan tugas rutin saja, tetapi mereka juga harus mampu menjalankan tugas tambahan dalam upaya untuk mempercepat tumbuh kembangnya sekolah.

\section{c. Kegiatan Belajar Mengajar (KBM)}

Model, strategi, dan metode pembelajaran sudah banyak berubah. Kalau guru-guru kita masih menggunakan cara lama/konvensional ketika mengajar peserta didiknya di depan kelas, dan tidak mau mengikuti model pembelajaran modern sebagaimana yang terjadi di sekitarnya, maka sekolah tersebut juga akan ditinggal para pelanggannya. Seperti contohnya model pembelajaran e-learning diamana pembelajaran telah berbasis dengan teknologi canggih sudah mulai merambah di dunia pendidikan, pemakain LCD dalam penyampaian materi pembelajaran. Contoh tersebut membuat siswa menjadi lebih tertarik untuk belajar.

Masalah yang dihadapi disekolah-sekolah yaitu selain kurangnya sarana penunjang, juga lemahnya Sumber daya pendidik yang ada dalam memanfaatkan dan mendayagunakan perlatan teknologi tersebut untuk proses pembelajaran. Langkah yang harus dilakukan oleh kepala sekolah yaitu, menugaskan guru-gurunya untuk mau belajar mengoperasikan peralatan, mengadakan pelatihan pemanfaatan ICT untuk pembelajaran, memantau proses pembelajaran sambil memberikan bimbingan pola pembelajaran, lesson study, dan lain sebagainya.

Dalam kurikulum 2013 proses pembelajaran tidak hanya dilakukan di dalam kelas saja, melainkan juga harus dilakukan di luar kelas, selain itu guru juga harus kreatif dalam menyiapkan kegiatan/pengalaman belajar bagi anak, juga dalam memilih kompetensi dari berbagai mata pelajaran dan mengaturnya agar pembelajaran menjadi lebih bermakna, menarik, menyenangkan dan utuh. Konsep pembelajaran dalam implementasi kurikulum 2013 adalah penerapan pendekatan tematik scientific (meliputi: mengamati, menanya, mencoba, mengolah, menyajikan, menyimpulkan, dan mencipta untuk semua mata pelajaran) dan penilaian autentik yaitu penilaian yang menilai hasil belajar peserta didik untuk ranah kognitif (pemahaman), afektif (sikap), adan psikomotor (keterampilan).

Kepala sekolah sebagai pimpinan di sekolah dasar, tentunya harus mempunyai program yang matang, untuk mempersiapkan para stakeholder, salah satunya guru sebagai pendidik yang akan melaksanakan kurikulum 2013, yaitu dengan mengadakan pelatihan-pelatihan, aktif dalam forum kegiatan KKG, lesson study, mengikuti seminar dan lain sebagainya.

\section{d. Desain pegelolaan kelas}

1). Penataan lingkungan fisik kelas

Lingkungan fisik kelas yang baik 
adalah ruangan kelas yang menarik, efektif, serta mendukung siswa dan guru dalam proses pembelajaran. Perubahan pada tujuan pembelajaran dan kegiatan belajar yang dilakukan siswa menuntut perubahan pada penataan lingkungan fisik kelas. Tugas utama guru adalah menciptakan suasana di dalam kelas agar terjadi interaksi belajar mengajar yang dapat memotivasi siswa untuk belajar dengan baik dan sungguh sungguh. Untuk itu, guru seharusnya memiliki kemampuan yang melakukan interaksi belajar mengajar yang baik. Salah satu kemampuan yang sangat penting adalah kemampuan mengatur kelas.

Hal ini perlu dilakukan Guru karena beberapa penelitian menunjukan bahwa penataan lingkungan kelas yang tepat berpengaruh terhadap tingkat keterlibatan dan partisipasi siswa dalam proses pembelajaran. Meskipun barang-barang yang ada di dalam kurang memadai keadaannya apabila di tata diatur dengan baik, barang-barang tersebut menjadi bemanfaat. Mengingat betapa pentingnya penataan lingkungan fisik kelas, Guru perlu memiliki kemampuan dalam penataan lingkungan kelas, baik penataan tempat duduk maupun penataan perabot kelas lainnya. Yang perlu diingat ialah bahwa tujuan utama penataaan lingkungan fisik kelas adalah mengarahkan kegiatan siswa dan mencegah kegiatan siswa dan mencegah munculnya tingkah laku siswa yang tidak diharapkan melalui penataan tempat duduk, perabot, pajangan dan barang-barang lainya yang ada dalam kelas. Lingkungan fisik kelas yang baik adalah ruangan kelas yang menarik, efektif serta mendukung siswa dan guru dalam proses pembelajaran. Agar proses pembelajaran dapat belangsung dengan baik guru harus menata tempat duduk dan barang-barang yang ada di ruangan kelas sehingga dapat mendukung proses pembelajaran.

Menurut Louisell (1992), ketika menata lingkungan kelas, Guru hendaknya memperhatikan hal-hal berikut:

a) Keleluasan pandangan (visibility)

Hal pertama yang harus diperhatikan Guru dalam menata ruangan kelas adalah keleluasan pandangan. Artinya, penempatan atau penataan barang-barang di dalam kelas tidak menggagu pandangan siswa sehingga siswa dapat secara leluasa memandang guru atau kegiatan yang sedang berlangsung serta guru juga dapat memandang siswa setiap saat menyajikan materi pelajaran.

b) Mudah dicapai (Accessibility)

Misalnya yang sering digunakan disimpan di dalam lemari kelas atau ruangan yang memungkinkan alat peraga tersebut dapat dipasang di dinding. Di samping itu, ruangan kelas juga hendaknya diatur dengan baik sehingga lalu lintas kegiatan belajar di kelas tidak terganggu .

c) Keluwesan (flexibilty)

Barang-barang yang ada di kelas hendaknya mudah untuk dipindahkan sehingga mudah ditata sesuai dengan tuntutan kegiatan pembelajaran yang akan dilakukan siswa dan guru. Pembelajaran melalui diskusi atau kerja kelompok akan menuntut tatanan ruangan kelas yang berbeda pembelajaran melalui kegiatan individual.

d) Kenyamanan

Prinsip kenyamanan ini berkenaan dangan temperatur ruangan, cahaya, suara dan kepadatan kelas. Kenyamanan ruangan kelas akan sangat berpengaruh terhadap konsentrasi dan produktifitas siswa dan guru dalam kegiatan pembelajaran. Hal ini dapat anda rasakan sendiri ketika anda mengikuti sesuatu penataan atau titorial. Selain itu kepadatan kelas juga mempengaruhi proses belajar Anda. 
Terlalu banyaknya peserta dalam satu ruangan menyebabkan anda harus berdesak-desakan pada satu meja. Keadaan ini menyebabkan anda tidak dapat mengikuti kegiatan dengan baik. Apabila siswa belajar dalam situasi seperti yang anda hadapi, siswa juga akan merasakan hal yang sama seperti yang anda rasakan. Disamping itu, masalah cahaya yang masuk kedalam ruangan dapat diatasi dengan penutup jendela.

e) Keindahan

Dalam menata ruangan kelas, guru juga perlu memperhatikan prinsip keindahan. Prinsip keindahan berkenaan dengan usaha guru untuk menciptakan ruangan kelas yang menyenangkan dan kondusif bagi kegiatan pembelajaran. Menata ruangan supaya indah tidak membutuhkan biaya yang banyak.Yang diperlukan adalah kesediaan guru dan siswa untuk selalu menjaga kebersihan dan kerapian ruangan. Ruangan kelas yang indah dan menyenangkan berpengaruh positif terhadap sikap dan tingkah laku siswa terhadap kegiatan pembelajaran yang dilaksanakan.

Penyusunan dan pengaturan ruang belajar hendaknya memungkinkan anak duduk bekelompok dan memudahkan guru bergerak secara leluasa untuk membantu dan memantau tingkah laku siswa dalam belajar.

2). Penataan Lingkungan Psiko-Sosial Kelas

Lingkungan psiko-sosial kelas berkenaan dengan hubungan personal sosial antara guru dengan siswa dan antar siswa. Guru yang membantu siswa yang membutuhkan akan mendorong siswa untuk giat belajar dan bekerja dengan baik. Siswa akan bekerja sama dan bersaing dengan cara yang sehat karena mereka merasa diperlakukan dengan adil. Selain itu, guru yang terbuka dan menerima siswa apa adanya akan memungkinkan siswa merasa aman dalam mengikuti pelajaran. Siswa akan berani mengajukan pertanyaan atau pendapat. Oleh karena itu, guru dituntut untuk mampu menata lingkungan psiko-sosial kelas yang harmonis baik antara guru dengan siswa dan antar siswa agar proses pembelajaran berlangsumg secara efektif.

a) Perilaku Guru sebagai berikut:

(1) Disukai oleh siswanya

(2) memiliki persepsi yang realistik tentang dirinya dan siswanya.

(3) Akrab dengan siswa dalam batas hubungan guru dan siswa

(4) Bersikap positif terhadap pertanyaan atau respon siswa

(5) Sabar, teguh, dan tegas

b) Kegiatan kelompok

(1) Pengelompokkan menurut kesenangan berkawan

Pada pengelompokkan ini kelas dibagi beberapa kelompok (jumlah kelompok bergantung pada besarnya kelas) atas dasar perkawanan/ kesenangan bergaul diantara mereka. Kelompok terdiri dari 4-6 orang atau lebih yang menurut mereka merupakan kawan-kawan dekat. Mereka duduk mengelilingi meja yang telah disusun sedemikian rupa dalam keadaan berhadapan. Dalam pengelompokkan seperti ini, setiap siswa mempelajari atau berbuat hal yang sama dengan sumber yang sama.

(2) Pengelompokkan

menurut kemampuan

Kenyataan menunjukkan bahwa ada siswa yang pandai, sedang, dan lembat dalam mempelajari sesuatu. Untuk memudahkan pelayanan guru, siswa dikelompokkan ke dalam kelompok cerdas, sedang/menengah, dan lambat. Pengelompokkan seperti ini diubah sesuai 
dengan kesanggupan individual dalam mempelajari mata pelajaran. Seorang siswa mungkin cerdas dalam matematika, tetapi lambat ilmu-ilmu social, sedsangkan siswa lain keadaannya tidak demikian. Pengelompokkan demikian akan menuntut program-program khusus untuk membantu siswa-siswa tertentu yamg mengalami kesulitan khusus dalam mata pelajaran tertentu.

\section{e. Peningkatan profesionalitas sumber daya pendidik (guru)}

Lampiran Permendiknas nomor 16 tahun 2007 tentang Standar Kualifikasi Akademik dan Kompetensi Guru menjelaskan bahwa Guru pada SD/MI, atau bentuk lain yang sederajat, harus memiliki kualifikasi akademik pendidikan minimum diploma empat (D-IV) atau sarjana (S-1) dalam bidang pendidikan SD/MI (D-IV/S1PGSD/PGMI) atau psikologi yang diperoleh dari program studi yang terakreditasi.

Permendiknas tersebut, merupakan salah satu aturan yang memperjelas profesionalitas guru, melalui jenjang pendidikan minimal S-1 PGSD, untuk guru kelas. Sehingga, sekolah dalam hal ini harus mempunyai suatu program dan kebijakan berupa memberikan kesempatan kepada guruguru untuk mengembangkan potensi akademiknya dalam melanjutkan studi pendidikan ke jenjang yang lebih tinggi minimal S-1 bahkan kalau bisa sampai S-2 asalkan secara linear yang sesuai dengan profesi yang digelutinya.

Peran kepala sekolah yang lain dalam meningkatkan profesionalitas sumber daya pendidik yaitu, tanggap terhadap hak dan kewajiban para bawahannya, misalnya mengecek kenaikan pangkat guru-gurunya secara berkala, menugaskan kepada guru- gurunya untuk aktf dalam forum dan kegiatan ilmiah, salah satunya pembuatan Penelitian Tindakan Kelas (PTK) minimal 1 tahun 1 PTK untuk setiap guru.

\section{Kesimpulan}

Peran kepala sekolah dalam mempersiapkan sumber daya pendidik (guru) menghadapi imlementasi kurikulum 2013 yaitu sebagai perencana dan pengembang dalam memberikan sebuah kebijakan sekolah yaitu dengan peningkatan dari segi pelayanan pembelajaran, konsep kegaitan pembelajaran yang menerapkan konsep pendekatan tematik scientific, menumbuhkan iklim budaya sekolah yang harmonis dan berkarakter sehingga pembelajaran dapat berjalan secara kondusif, peningkatan profesionalitas akademik pendidiknya melalui jalur pendidikan dan pelatihan, dan menanamkan kebersamaan serta kerja sama antar stakeholder dalam membangun dan mengembangkan program sekolah.

Kepala sekolah sebagai perencana dalam pelaksanaannya peran dari semua stakeholder yang akan menentukan sukses tidaknya suatu program yang telah direncanakan untuk itu dibutuhkan kerja sama dan dukungan dari stakeholder. Sehingga, diharapkan mempunyai rasa memiliki dan ikut berjanggung jawab dalam mensukseskan program tersebut.

\section{Daftar Pustaka}

Depdiknas., 2003. Undang-undang Republik Indonesia Nomor 20 Tahun 2003 tentang Sistem Pendidikan Nasional. Jakarta: Depdiknas.

Depdiknas., 2005. Undang-undang Republik Indonesia Nomor 14 Tahun 2005 tentang Guru dan Dosen. Jakarta: Depdiknas. 
Depdiknas., 2007. Peraturan Menteri Pendidikan Nasional Republik Indonesia Nomor 13 Tahun 2007 tentang Standar Kepala Sekolah/Madrasah. Jakarta: Depdiknas.

Depdiknas., 2007. Peraturan Menteri Pendidikan Nasional Republik Indonesia Nomor 16 tahun 2007 tentang Standar Kualifikasi Akademik dan Kompetensi Guru. Jakarta: Depdiknas.

Kemdikbud., 2013. Salinan Lampiran Peraturan Menteri Pendidikan dan Kebudayaan Repubik Indonesia No. 67 Tahun 2013 tentang Kerangka Dasar dan Struktur Kurikulum SD/MI. Jakarta: Kemdikbud.

Mulyana, A.Z., 2010. Rahasia Menjadi Guru Hebat (Motivasi Diri Menjadi Guru Luar Biasa). Jakarta: PT. Gramedia Widiasarana Indonesia

Mulyana, A.Z., 2012. Reformation Marketing Sekolah, Cara Cerdas "Membesarkan Sekolah”. Surabaya: Penerbit Bening Pustaka.

Semiawan, Conny.dkk., 1992. Pendekatan Keterampilan Proses. Jakarta: PT Gramedia Widiasarana Indonesia.

Suryosubroto, 2010. Manajemen Pendidikan di Sekolah. Jakarta: Rieneka Cipta. 